\title{
MOLECULAR DETECTION OF ANAPLASMA MARGINALE IN THE EGYPTIAN WATER BUFFALOES (BUBALUS BUBALIS) BASED ON MAJOR SURFACE PROTEIN 1a
}

\author{
By \\ MAHMOUD D. ELHARIRI ${ }^{1}$, REHAB A. ELHELW ${ }^{1^{*}}$, DALIA A. HAMZA ${ }^{2}$ \\ and DOAA E. SOLIMAN ${ }^{3}$
}

Departments of Microbiology ${ }^{1}$, and Zoonosis ${ }^{2}$, Faculty of Veterinary Medicine, Cairo

University, Giza 12613 and Department of Entomology ${ }^{3}$, Faculty of Science, Ain

Shams university, Cairo 11566, Egypt ('Correspondence: rehab.elhelw@cu.edu.eg)

Abstract

Anaplasmosis is an infectious, non-contagious disease caused by the rickettsial pathogen Anaplasma marginale. The organism is globally distributed and infects erythrocytes, resulting in anemia, jaundice, fever, abortions and death. Once infected, animals remain carriers for life. In developing countries anaplasmosis is of great economic losses as it is highly endemic.

The present study was designed to determine the prevalence of $A$. marginale in blood samples of buffaloes since they are important reservoir hosts for $A$. marginale and can serve as a source of infection for tick. A total of 150 buffalo blood samples was randomly collected from four governorates and was analyzed using PCR assay based on msp1 $\alpha$. Anaplasma marginale DNA was detected in $69.3 \%(104 / 150)$ of the sampled buffaloes, and $86.6 \%(130 / 150)$ of collected ticks. As anaplasmal infection is endemic in Egypt, it was recommended screening herds to detect $A$. marginale even when the signs and symptoms of infection were not visible.

Keywords: Egypt, Anaplasma marginale, Buffaloes, Ticks, mspl $\alpha$ gene, PCR.

\section{Introduction}

The domestic water buffalo (Bubalus bubalis) contributes a significant share of global milk production and is the major milk producing animal in several countries including Egypt. Buffaloes are kept mostly by smallscale producers in developing countries, who raise one or two animals in mixed croplivestock systems.

Anaplasma marginale is an obligate intracellular Gram-negative bacterium classified in the family Anaplasmataceae of Order Rickettsiales. The socioeconomic impact of the disease and the restrictions on trading infected animals internationally led the Office International des Epizooties (OIE) Animal Health Code to categorize anaplasmosis as a disease that required the notification of its presence (OIE, 2008).

The epizootiology of anaplasmosis is complicated by the life-long carrier state which occurs in animals that have recovered from the clinical disease (Atif, 2015). It is transmitted biologically by tick species of genera (Ixodes, Dermacentor, Rhipicephalus, and Amblyomma) and mechanically by other blood-sucking insect-vectors and fomites (Liz et al, 2000; Walker et al, 2001; Skotarczak et al, 2003). It is the most prevalent pathogen transmitted by ticks in the third world. It was found on six continents (Kocan et al, 2010) and causes anap-lasmal infection globally in tropical and subtropical (Lew and Jorgensen, 2005; Ryma-szewska and Grenda, 2008) as well as temp-erate regions worldwide (Ohashi et al, 2005; Woldehiwet, 2006; Bakken and Dumler, 2008).

Although the clinical signs are rare in buffaloes, their treatment is essential as they may act as carriers for cattle (Vatsya et al, 2013). Clinical anaplasmosis is most notable in cattle, but other ruminants including water buffalo (Bubalus bubalis), American bison (Bison bison) were also affected (Kuttler, 1984; Zaugg et al, 1996). Various forms of the anaplasmal infection reduced the body weight of infected animals, causing abortions, reduction in milk production, and frequently led to death causing the economic losses to livestock owners (Sainz et al, 1999; Melendez, 2000; Stuen et al, 2002). The bovine anaplasmosis often resulted in devel- 
opment of mild to severe anemia and icterus without hemoglobinemia and hemoglobinuria. The clinical symptoms included fever, weight loss, abortion, lethargy, icterus, and often death in the animals over two years old (Kocan et al, 2003; 2004).

The major surface protein 1 alpha (MSP1a) has been used as a marker to characterize the genetic diversity and identification of A. marginale strains (Silva et al, 2014). Also, because of it is involved in the interaction of the bacterium with vertebrate and 63 invertebrate host cells (de la Fuente et al, 2010), detection of persistently infected cattle is important to control the movement of infected cattle into and from the disease-free regions, however, not in buffaloes. Several reports are available on anaplasmosis in the Egyptian cattle (Kumar and Sangwan, 2010; Nair et al, 2013), however, there was little information regarding the buffaloes (Ashuma et al, 2013).

The present study screened the incidence of Anaplasma marginale in Egyptian buffaloes by using the reliable molecular tool in four representative Egyptian Governorates.

\section{Materials and Methods}

Ticks collection and Identification: Ticks were taken off each buffalo from which blood samples had been taken. Only the non-en-gorged adults were identified. Collected ticks were transferred to the laboratory where they were killed with hot water and identified to the species level according to Hoogstraal (1981) keys, using the stereo microscope. To overcome contamination problem, the surface of ticks can be sterilized by washing them in $70 \%$ ethanol and rinsed with sterile water (Wittenbrink et al, 1994; Higgins and Azad 1995; Zhang et al, 1995). The identified sterilized ticks were stored individually in the $1.5-\mathrm{ml}$ micro-centrifuge tubes containing $70 \%$ ethanol and stored at $20^{\circ} \mathrm{C}$ prior to the DNA extraction.

DNA extraction of collected ticks: DNA extraction was performed using Qiamp DNA extraction kit for tissue protocol (Qiagen, Cat No./ID: 56404). Firstly, the ticks were roughly torn to pieces in $180 \mu \mathrm{l}$ ATL buffer and treated with proteinase $\mathrm{K}(100 \mu \mathrm{g} / \mathrm{mL})$ for $16 \mathrm{~h}$ at $56^{\circ} \mathrm{C}$. The subsequent steps were carried out according to the manufacturer's instructions.

Blood samples collection: A total of 150 blood samples were collected from buffaloes highly infested by ticks from Giza, Qalyoubia, El-Wadi El-Gadeed and Menofia Govern-orates. Blood was collected from jugular vein in evacuated tubes containing EDTA.

DNA extraction of collected blood samples: DNA was extracted using QIAamp DNA blood mini kit (Qiagen, Cat No. ID: 51104) following the Manufacturer's instructions. The DNA concentration from each sample was quantified by using a NanoDrop spectrophotometer and stored at $-20{ }^{\circ} \mathrm{C}$.

Amplification of $A$. marginale DNA: The PCR amplification of $A$. marginale DNA based on mspla (Lew et al, 2002). PCR was per-formed in $25 \mu \mathrm{L}$ final volume containing $5 \mu 1$ of DNA template either from the ticks or from collected blood, $12.5 \mu \mathrm{L}$ of PCR Master Mix (Qiagen), 1.6 $\mu \mathrm{M}$ of forward \& reverse primers: $1733 \mathrm{~F}\left(5^{\prime}\right.$-TGTGCTTATGGCAGA CCATTTCC-3'), 3134R (5'-TCACGGTCA ACCTTTGCTTACC-3'), and the nucleasefree water to the final volume of $25 \mu \mathrm{l}$.

PCR was performed under the following conditions, an initial de-naturation at $94^{\circ} \mathrm{C}$ for $5 \mathrm{~min}, 40$ cycles of $94^{\circ} \mathrm{C}$ for $30 \mathrm{~s}, 55^{\circ} \mathrm{C}$ for $1 \mathrm{~min}$, and $72^{\circ} \mathrm{C}$ for $2 \mathrm{~min}$, followed by the final extension at $72^{\circ} \mathrm{C}$ for $7 \mathrm{~min}$. The PCR products were subject for $1.5 \%$ agarose gels electrophoresis. After the staining with ethidium bromide the PCR products were visualized using UV transilluminator (IN Geniuse 3) connected with the Quantity-one 4.6.2 software image capturing and analysis.

\section{Results}

The results are shown in fig. (1). 


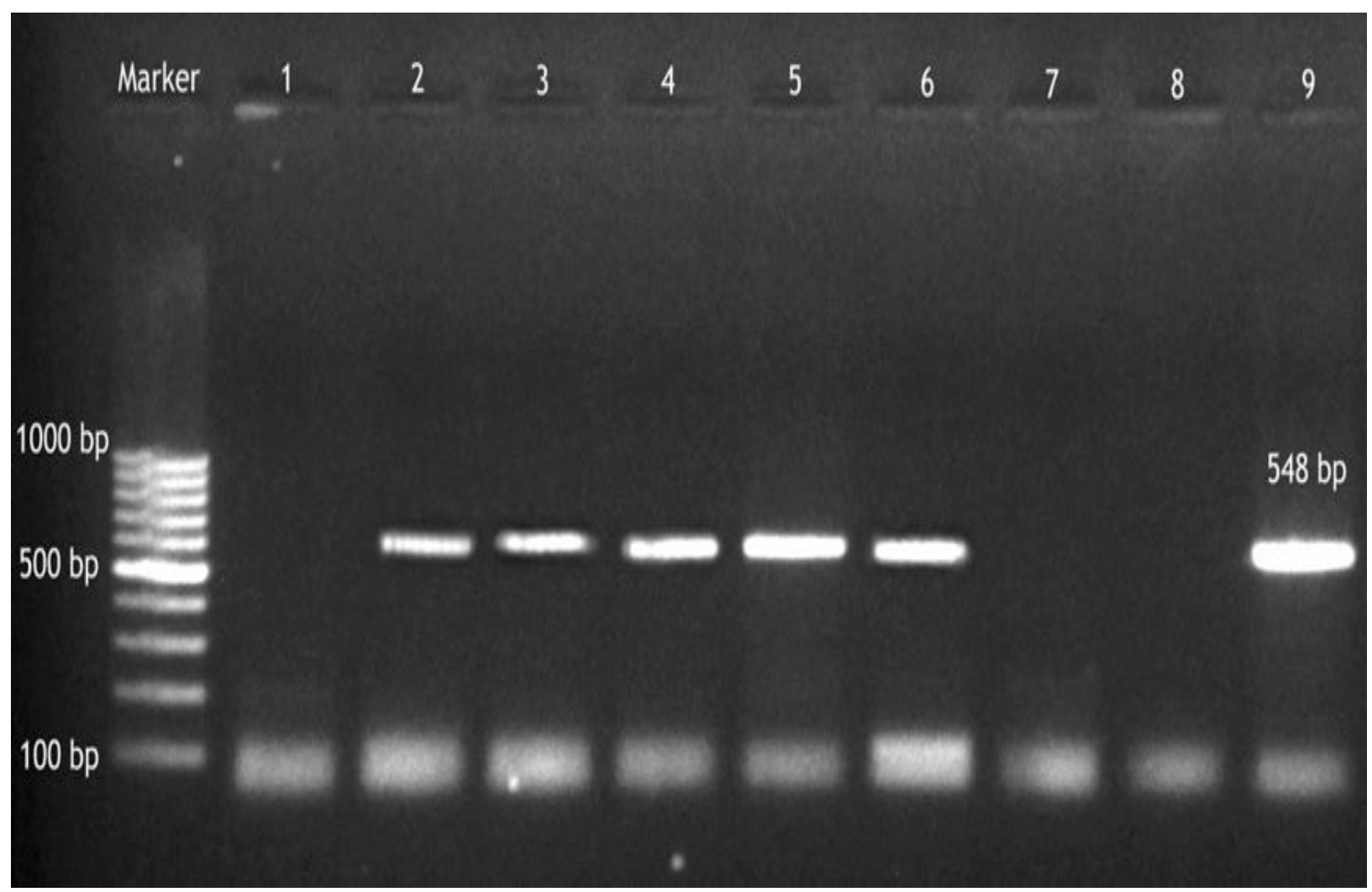

Fig. 1: Amplification of Mspl $\alpha$ at 548bp. Lane 1: negative PCR control, Lane 2, 3, and 4 amplified DNA extracted from blood samples, lanes 5, \& 6: amplified DNA extracted from collect ticks. Lane 9: positive control

Discussion

In the present study, the prevalence of $A n$ aplasma sp. varied from one region to another and a number of factors were associated with incidence of this tick-borne diseases including age, sex, breed, tick density, season, geographical area, and management (Stokka et al, 2000; Khan et al, 2004; Kivaria, 2006; Magona et al, 2011; Atif et al, 2012).

The expected PCR product from amplified A. marginale mspla gene was 548 bp (Fig. 1). A total of 500 adult hard ticks were collected and by using the pictorial key for the tick's identification, those of buffaloes belonged to Rhipicephalus (280), Boophilus (150), Hyalomma anatolicum anatolicum (30), and H. a. excavatum (40). The high infection rates were detected in the ticks (86.6\%) by amplified $m s p l \alpha$, using a microscopic examination, in Pakistan, the tick collected from the water buffaloes showed infection rate of $36.59 \%$.

In spite of the fact that the water buffaloes were exposed to $A$. marginale, a low rate of A. marginale PCR-positive animals were reported, which might be related to the habitat where the sampled animals lived because they exhibited a low rate of attached ticks to skin. The amplification of $A$. marginale mspl $\alpha$ gene showed that $69.3 \%$ of collected blood from the Egyptian buffaloes was positive A. marginale although these animals were apparently healthy without any clinical manifestation. Sajid et al. (2009) and Ocaido et al. (2005) reported $11.8 \%$ prevalence of A. marginale in cattle and buffaloes of Sorti District, Uganda. This difference might be attributed to the climatic conditions and/or habitat. The results agreed with Haider and Bilqees (1988) who reported 61\% Anaplas$m a$ sp. in Karachi and adjoining areas. This difference in the results might probably be due to the environmental and/or the climate conditions with relatively high humidity in Karachi that favor the tick-vector development and spreading (Shahnawaz et al, 2011). Also, serological and molecular de- 
tection of $A$. marginale in seventy-three water buffaloes in Brazil gave prevalence of $49.0 \%$ and $5.4 \%$, respectively (Silva et al, 2014).

Adjou Moumouni et al. (2015) in Kenya by using Nested PCR and sequencing reported the prevalence and genetic diversity of Babesia bovis, B. bigemina, Theileria species and $A$. marginale parasites in 192 cattle blood samples. The B. bovis spherical body protein $4, B$. bigemina rhoptry-associated protein 1a, A. marginale major surface protein 5, Theileria spp. 18S rRNA, $T$. parva $\mathrm{p} 104$ and $T$. orientalis major piroplasma surface protein were used as the marker genes. They concluded that results reaffirmed the endemicity and co-infection of cattle with tick-borne hemoparasites, and the role of wildlife in pathogens' transmission and population genetics, the buffaloes could serve as a source of zoonosis.

Michael et al. (1987) in El-Minia Governo-rate reported the first case of human babesiosis in a farmer. El-Bahnasawy and Morsy (2008) in Alexandria reported zoonotic ba-besiosis in a youth and El-Bahnasawy et al. (2011) in Cairo reported babesiosis in a boy who acquired the infection from his pet dog infested with ticks. Sazmand et al. (2016) in Iran reported that camels were identified as hosts for bovine Mediterranean theileriosis. Qiu et al. (2016) in China stated that domestic ruminants were infected with a variety of Anaplasma spp. and Ehrlichia spp Matei et al. (2017) in Romania evaluated the annual prevalence of Rickettsia spp. and $A$. phagocytophilum in I. ricinus collected from humans over three consecutive years. They concluded that prevalence of $R$. helvetica, suggested an increasing risk for the humans zoonotic pathogen. Battilani et al. (2017) in Italy stated that Anaplasma are the etiological agents of tick-borne diseases of veterinary and medical importance in both tropical and temperate regions

In Egypt, Loftis et al. (2006) detected A. marginale, Coxiella burnetii, Rickettsia aeschlimannii, and four novel genotypes simi- lar to: "Anaplasma platys," Ehrlichia canis, Herlichia spp. reported from the Asian ticks, and a Rickettsiales endosymbiont of Ixodes ricinus. El-Ashker et al. (2015) in Dakahlia Governorate used a novel DNA microarray system for diagnosing bovine piroplasmosis and anaplasmosis in comparison with microscopy and PCR assay. They found that in the acutely ill cattle, the $A$. marginale was 10/164 and mixed infections with Babesial Theileria spp. and A. marginale were in two more cases. Moreover, A. marginale infections were also detected in 23 of the apparently healthy cattle. Fereig et al. (2017) in southern Egypt reported antibodies against A. marginale in $25 / 90$ (28\%) of cattle.

\section{Conclusion}

Infection with $A$. marginale is more or less endemic not only in Egypt but also in many cattle rearing countries where tickvectors are common. There is a lack of the adequate information on its genotypes.

The present outcome results declared that A. marginale is highly prevalent in the Egyptian water buffaloes especially those apparently healthy. Undoubtedly, the control of tick-vectors and the early diagnosis and treatment of infected cattle would the save meat and meat production.

Conflict of interest: The authors have neither conflict of interest nor received financial support

\section{References}

Adjou Moumouni, PF, Aboge, GO, Terkawi, M A, Masatani, T, Cao, S, et al, 2015: Molecular detection and characterization of Babesia bovis, Babesia bigemina, Theileria species and Ana-plasma marginale isolated from cattle in Kenya. Parasit. Vectors 8:496. doi: 10.1186/s 13071015-1106-9.

Ashuma, SA, Singla, LD, Kaur, P, Bal, MS, Batth, BK, Juyal, PD, 2013: Prevalence and haematobiochemical profile of Anaplasma marginale infection in dairy animals of Punjab (India). Asian Pacific J. Trop. Med. 6:139-44.

Atif, FA, Khan, MS, Iqbal, HJ, Roheen, T, 2012: Prevalence of tick-borne diseases in Punjab (Pakistan) and hematological profile of Anaplasma marginale infectionin indigenous and cross-bred cattle. Pak. J. Sci. 64:1-5. 
Bakken, JS, Dumler, S, 2008: Human granulocytic anaplasmosis. Infect. Dis. Clin. North Am. 22:433-48.

Battilani, M, De Arcangeli, S, Balboni, A, Dondi, F, 2017: Genetic diversity and molecular epidemiology of Anaplasma. Infect. Genet. Evol. 49:195-211.

de la Fuente, J, Kocan, KM, Blouin, EF, Zivkovic, Z, Naranjo, V, et al, 2010: Functional genomics and evolution of tick-Anaplasma interactions and vaccine development. Vet. Parasitol. 167:175-86

El-Ashker, M, Hotzel, H, Gwida, M, El-Beskawy, M, Silaghi, C, et al, 2015: Molecular biological identification of Babesia, Theileria, and Anaplasma species in cattle in Egypt using PCR assays, gene sequence analysis and a novel DNA microarray. Vet. Parasitol. 207, 3/4:329-34.

El-Bahnasawy, MM, Morsy, TA, 2008: Egyptian human babesiosis and general review. J. Egypt. Soc. Parsitol. 38, 1:265-72.

El-Bahnasawy, MM, Khalil, HHM, Morsy, T A, 2011: Babesiosis in an Egyptian boy acquired from pet dog, and a general review. J. Egypt. Soc. Parasitol. 41, 1:99-108

Fereig, RM, Mohamed, SG, Mahmoud, HY, AbouLaila, MR, Guswanto, A, et al, 2017: Sero-prevalence of Babesia bovis, B. bigemina, Trypanosoma evansi, and Anaplasma marginale antibodies in cattle in southern Egypt. Ticks Tick Borne Dis. 8, 1:125-31.

Haider, MJ, Bilqees, FM, 1988: Anaplasmosis in certain mammals in Karachi and adjoin areas. Proc. Parasitol. 6:85-8.

Higgins, JA, Azad, AF, 1995: Use of polymerase chain reaction to detect bacteria in arthropods: A review. J. Med. Entomol. 32:213-22

Hoogstraal, H, 1981: Changing patterns of tick borne diseases in modern society. Ann. Rev. Entomol. 26:75-99

Loftis, AD, Reeves, WK, Szumlas, DE, Abbassy, MM, Helmy, IM, et al, 2006: Rickettsial agents in Egyptian ticks collected from domestic animals. Exp. Appl. Acarol. 40, 1:67-81.

Khan, MQ, Zahoor, A, Jahangir, M, Mirza, MA, 2004: Prevalence of blood parasites in cattle and buffaloes. Pak. Vet. J. 24:193-5.

Kivaria, FM, 2006: Estimated direct economic costs associated with tick-borne diseases on cattle in Tanzania. Trop. Anim. Hlth. Prod. 38:2919.

Kocan, KM, de la Fuente, J, Guglielmone, A A, Melende'z, RD, 2003: Antigens and alterna- tives for control of Anaplasma marginale infection in cattle. Clin. Microbiol. Rev. 16: 698-712. Kocan, KM, de la Fuente, J, Blouin, EF, Garcia-Garcia, JC, 2004: Anaplasma marginale (Rickettsiales: Anaplasmataceae): Recent advances in defining host-pathogen adaptations of a tick-borne rickettsia. Parasitology 129:S285-300.

Kocan, KM, de la Fuente, J, Blouin, EF, Coetzee, JF, Ewing, SA, 2010: The natural history of Anaplasma marginale. Vet. Parasitol. 167:95107.

Kumar, PP, Sangwan, AK, 2010: Comparative prevalence of subclinical bovine anaplasmosis under different cattle management. Haryana Veterinarian 49:1-5.

Kuttler, KL, 1984: Anaplasma infections in wild and domestic ruminants: a review. J. Wildlife Dis. 20:12-20.

Lew, AE, Bock, RE, Minchin, CM, Masaka, S, 2002: Amspla polymerase chain reaction assay for specific detection and differentiation of Anaplasma marginale isolates. Vet. Microbiol. 86:325-35.

Lew, A, Jorgensen, W, 2005: Molecular approaches to detect and study the organisms causing bovine tick borne diseases, babesiosis and anaplasmosis. Afr. J. Biotechnol. 4:292-302.

Liz, JS, Anderes, L, Sumner, JW, Massung, R F, Gern, L, et al, 2000: PCR detection of granulocytic ehrlichiae in Ixodes ricinus ticks and wild small mammals in western Switzerland. J. Clin. Microbiol. 38:1002-7.

Magona, JW, Walubengo, J, Olaho-Mukani, W, Jonsson, NN, Welburn, SW, et al, 2011: Spatial variation of tick abundance and sero-conversion rates of indigenous cattle to Anaplasma marginale, Babesia bigemina and Theirleria parva infections in Uganda. Exp. Appl. Acarol. 55: 203-13.

Matei, IA, Kalmár, Z, Lupşe, M, D'Amico, G, Ionică, AM, et al, 2017: The risk of exposure to rickettsial infections and human granulocytic anaplasmosis associated with Ixodes ricinus tick bites in humans in Romania: A multiannual study. Ticks Tick-Borne Dis. 8, 3:375-8.

Melendez, RD, 2000: Future perspective on veterinary hemoparasite research in the tropic at the start of this century. Ann. N. Y. Acad. Sci. 916: 253-8.

Michael, SA, Morsy, TA, Montasser, MF, 1987: A case of human babesiosis (Preliminary case report in Egypt). J. Egypt. Soc. Parasitol. 17, 1:409-10. 
Nair, AS, Ravindran, R, Lakshmanan, B, Sreekumar, C, Kumar, SS, et al, 2013: Bovine car-riers of Anaplasma marginale and Anaplasma bovis in South India. Trop. Biomed. 30, 1: 105-12.

Ocaido, M, Otim, CP, Okuna, NM, Erume, J, Ssekitto, C, et al, 2005: Socio-economic and live-stock disease survey of agropastoral communities in Serere County, Soroti District, Uganda. Livestock, Res. Rur. Dev. 17:8-10.

Ohashi, N, Inayoshi, M, Kitamura, K, Kawamori, F, Kawaguchi, D, et al, 2005: Anaplasma phagocytophilum infected ticks, Japan. Emerg. Infect. Dis. 11:1780-3.

OIE 2008: The World Organization for Animal Health. In: Manual of Standards for Diagnostic Tests and Vaccines for Terrestrial Animals, $6^{\text {th }}$ edition.

Qiu, H, Kelly, PJ, Zhang, J, Luo, Q, Yang, Y, et al, 2016: Molecular detection of Anaplasma spp. and Ehrlichia spp. in ruminants from twelve Provinces of China. Can. J. Infect. Dis. Med. Microbiol. 2016:9183861. doi:10.1155/2016/ 91 83861, Epub 2016 Dec 20.

Rymaszewska, A, Grenda, S, 2008: Bacteria of the genus Anaplasma characteristics of Anaplasma and their vectors, a review. Vet. Med. 11: 573-84.

Sainz, A, Amusategui, I, Tesouro, MA, 1999: Ehrlichia platys infection and disease in dogs in Spain. J. Vet. Diag. Invert. 11:382-4.

Sajid, MS, Iqbal, Z, Khan, MN, Muhammad, G, Khan, MK, 2009: Prevalence and associated risk factors for bovine tick infestation in two districts of lower Punjab, Pakistan. Prev. Vet. Med. 92:386-91.

Sazmand, A, Eigner, B, Mirzaei, M, Hekmatimoghaddam, SH, Harl, J, et al, 2016: Molecular identification of hemoprotozoan parasites in cam-els (Camelus dromedarius) of Iran. Iran J. Para-sitol. 11, 4:568-73.

Shahnawaz, S, Ali, M, Aslam, MA, Fatima, R, Chaudhry, ZI, et al, 2011: A study on the prevalence of a tick-transmitted pathogen Theileria annulata, and hematological profile of cattle from Southern Punjab (Pakistan). Parasitol. Res. 109, 1155-60.
Silva, JB, Santos, PN, Santana Castro, GN, Fonseca, AH, Barbosa, JD, 2014: Prevalence Survey of Selected Bovine Pathogens in Water Buffaloes in the North Region of Brazil. Parasitol. Res. Article ID 603484, 4 pages http:// dx. doi.org/10.1155/2014/603484.

Skotarczak, B, Rymaszewska, A, Wodecka, B, Sawczuk, M, 2003: Molecular evidence of coinfection of Borrelia burgdorferi sensu lato, human granulocytic ehrlichiosis agent and Babesia microti in ticks from north-western Poland. J. Parasitol. 89:194-6.

Stokka, G, Faulkner, R, Van Boening, J, 2000: Anaplasmosis: Agricultural Experiment Station and Cooperative Extension Service. Kansas State University, USA.

Stuen, S, Bergström, K, Palmér, E, 2002: Reduced weight gain due to subclinical Anaplasma phagocytophilum (formerly Ehrlichia phagocytephila) infection. Exp. App. Acarol. 28:209-15. Vatsya, S, Kumar, RR, Singh, VS, Arunraj, MR, 2013: Anaplasma marginale infection in a buffalo: A case report. Vet. Res. Int. 1, 2:51-3.

Walker, AR, Alberdi, MP, Urquhart, KA, 2001: Risk factors in habitats of the ticks Ixodes ricinus influencing human exposure to Ehrlichia phagocytophila bacteria. Med. Vet. Entomol. 15, 2:40-9.

Wittenbrink, MM, Thiele, D, Krauss, H, 1994: Comparison of darkfield microscopy, culture, and polymerase chain reaction (PCR) for detection of Borrelia burgdorferi in the fieldcollected Ixodes ricinus ticks. Zentralbl Bakteriol. 281:183-91

Woldehiwet, Z, 2006: Anaplasma phagocytephilum in ruminants in Europe. Ann. N.Y. Acad. Sci. 1078:446-60.

Zaugg, JL, Goff, WL, Foreyt, W, Hunter, DL, 1996: Susceptibility of elk (Cervus elaphus) to experimental infection with Anaplasma marginale and A. ovis. J. Wild life Dis. 32:63-6.

Zhang, M, Gothe, R, Rinder, H, 1995: Detection of spotted fever group rickettsiae in ticks and rodents by PCR technique in People's Republic of China. Acta Virol. 39:263-7. 